\title{
KONSTRUKSI NILAI INKLUSIF TOKOH AGAMA DALAM MEMANDANG PLURALITAS AGAMA DI KEDIRI
}

\author{
Khaerul Umam \\ Institute Agama Islam Negeri Kediri \\ Email: khaerulumam1704@gmail.com
}

\begin{abstract}
: religious view toward other different groups often lead to conflicts. The ability of a religious person to view differences as a gift shows a high level of religious awareness. However, religious diversity often becomes a challenge when it deals with economic and political interests. Through phenomenological approach, this study aims to see the construction of the inclusive value of religious leaders in Kediri. This research found that the construction of inclusive values has been shaped by three main factors: (1) social culture which improves values and norms encouraging individual behaviour and attitudes; (2) historical factors, and (3) religious experience, namely a practice and behavior of the religious leaders.
\end{abstract}

Pola pandang terhadap keragaman dan perbedaan bisa menimbulkan dan menyulut sebuah konflik. Kemampuan seseorang melihat perbedaan sebagai sebuah anugerah adalah kesadaran yang sangat bernilai, sebab terkadang keragaman justru menjadi ancaman tersendiri ketika ia bersinggungan dengan kepentingan ekonomi dan politik. Menggunakan pendekatan fenomenologi studi ini bermaksud melihat konstruksi nilai inklusif tokoh agama di kota Kediri. Penelitian ini menemukan bahwa konstruksi nilai inklusif tokoh agama dibentuk setidaknya oleh tiga hal: (1) budaya sosial, (2) faktor sejarah, dan (3) pengalaman keagamaan.]

Keywords: Inclusive value, religious leaders, religious plurality. 


\section{Pendahuluan}

Laporan Komnas HAM yang disampaikan pada 23 Februari 2016 menyatakan bahwa pengaduan atas kasus pelanggaran kebebasan beragama dan berkeyakinan yang diterima lembaga ini meningkat dari 74 pengaduan pada 2014 menjadi 87 pengaduan pada 2015. Senada dengan hal tersebut, laporan Setara Institute yang disampaikan pada 18 Januari 2016 juga menyatakan bahwa pada 2014 terdapat 134 kasus pelanggaran di berbagai wilayah Indonesia, tetapi pada 2015 meningkat menjadi 197 kasus. Sementara tindakan pelanggaran pada 2014 berjumlah 177 dan pada 2015 meningkat menjadi 236 tindakan. ${ }^{1}$

Laporan tersebut tidak hanya menjadi pukulan telak bagi bangunan budaya kerukunan umat beragama, tetapi juga bagi kelangsungan hidup berbangsa dan bernegara. Dalam bingkai negara, setiap warga seharusnya diposisikan setara dan tidak ada dominasi atas yang lain dalam meyakini sebuah agama. Hal tersebut diatur tegas dalam Undang-Undang Dasar. ${ }^{2}$ Namun faktanya, bangsa ini justru menunjukkan gejala sebaliknya, di mana kelompok yang merasa memiliki suara mayoritas terkesan kurang menghargai minoritas. Contoh yang mungkin paling mudah dan relevan untuk menunjukkan signifikansi dari hal ini adalah kekerasan antar umat beragama yang terjadi terhadap kelompok minoritas Muslim yang dianggap "menyimpang" seperti Ahmadiyah di Jawa Barat, ${ }^{3}$ Syiah di

\footnotetext{
1 MasykuriAbdillahdalam http://graduate.uinjkt.ac.id/index.php/akademik/2016-1201-09-12-13/12-kolom-irektur/156-kerukunan-umat-beragama-di-era-jokowijk.(diunduh pada 28 September 2018).

2 Lihat Undang-Undang hak-hak Kebebasan Beragama dan Berkeyakinan (KBB) beserta dinamika persoalan-persoalan yang belum selesai dan diskusi lebih lanjut tentang persoalan tersebut dalam Zainal Abidin Bagir, et al., Membatasi Tanpa Melanggar: Hak Kebebasan Beragama atau Berkeyakinan (Yogyakarta: CRCS, 2019).

${ }^{3}$ Definisi minoritas di sini tidak hanya berlaku untuk non-Muslim saja, tetapi juga pada komunitas Muslim sendiri yang dalam hal ini adalah Ahmadiyah. Mereka diperlakukan bahkan lebih buruk daripada non-Muslim. Lihat: Ahmad Najib Burhani, "Treating Minorities with Fatwas: A Study of the Ahmadiyya Community in Indonesia," Contemporary Islam, 8.3 (2014): 285-301. Lebih jauh, ada indikasi keterlibatan pemerintah dalam proses "minoritisasi" Ahmadiyah ini. Lihat Amin Mudzakkir, "Minoritisasi Ahmadiyah di Indonesia," Masyarakat Indonesia, 37.2 (2011): 1-25. Bandingkan juga dengan Melissa Crouch, "Ahmadiyah in Indonesia: A History of Religious Tolerance Under Threat?” Alternative Law Journal, 36.1 (2011): 56-57.
} 
Sampang, ${ }^{4}$ dan Gafatar di Sumatera Utara, ${ }^{5}$ serta persoalan yang cukup kompleks dan berkepanjangan terkait dengan paradigma agama yang dipakai oleh negara dalam menginklusi beberapa agama dan mengeksklusi yang lain, dalam hal ini rekognisi terhadap apa yang disebut sebagai "agama leluhur" atau "agama lokal."

Di satu sisi, kebijakan pemerintah untuk mengosongkan kolom agama di pencatatan sipil seperti Kartu Tanda Penduduk (KTP) dan Kartu Keluarga (KK) - yang sebelumnya hanya diperuntukkan bagi enam agama yang diakui oleh negara-menunjukkan adanya "kemajuan" terkait dengan pengakuan dan pelayanan negara terhadap para pemeluk "agama leluhur" tersebut. Tetapi di sisi lain, kebijakan ini dianggap masih memiliki konsekuensi yang diskriminatif terhadap pemeluk "agama leluhur" atau "agama lokal," yakni tetap menegaskan anggapan bahwa mereka masih belum atau tidak beragama (biasanya dengan tuduhan ateis dan atau komunis), yang akhirnya berimplikasi pada relasi kuasa yang tidak setara dalam wacana publik dan ruang politik. ${ }^{6}$

Persoalan lain yang tidak kalah penting untuk disoroti adalah munculnya gerakan polulisme Islam yang diawali oleh kasus penistaan agama yang menimpa salah satu calon gubernur, Basuki Tjahaya Purnama (Ahok), pada pilkada Jakarta 2017 lalu. Kemanangan Anies Baswedan dan Sandiaga Uno sebagai gubernur dan wakil gubernur pada pilkada tersebut dianggap sebagai kemenangan mayoritas (Islam) terhadap minoritas (Cina-Kristen), dan oleh karena itu juga berarti kemenangan intoleransi atas toleransi. ${ }^{7}$ Tidak hanya itu, kasus yang

${ }^{4}$ Konflik antara Sunni dan Syi'ah di Sampang juga terjadi dalam kurun waktu yang berdekatan dengan konflik Ahmadiyah di Jawa Barat. Hal ini mengindikasikan adanya unsur politik yang melampaui faktor teologis semata. Lihat dinamikanya dalam Muhammad Afdillah, Dari Masjid ke Panggung Politik: Melacak. Akar-akar Kekerasan Agama antara Komunitas Sunni \& Syiah di Sampang, Jawa Timur (Yogyakarta: CRCS, 2016). Bandingkan dengan analisis ekonomi politik kasus ini dalam Masdar Hilmy, "The Political Economy of Sunni-Shi'ah Conflict in Sampang Madura," Al-Jami'ab: Journal of Islamic Studies, 53.1 (2015): 27-51.

5 Paul Marshall, "The Ambiguities of Religious Freedom in Indonesia," The Review of Faith \& International Affairs, 16.1 (2018): 91.

${ }^{6}$ Penjelasan lebih panjang terkait hal ini lihat Samsul Ma'arif, Pasang Surut Rekognisi Agama Lelubur dalam Politik. Agama di Indonesia (Yogyakarta: CRCS, 2017).

${ }^{7}$ Lihat bagaimana beberapa media menyoroti kasus ini dalam kerangka politik identitas, misalnya dalam New York Times, https://www.nytimes.com/2017/- 
berhasil mengundang perdebatan di lingkungan akademik, terutama seputar gerakan Islam dan politik, menghasilkan perbedaan analisis dan kompleksitas metodologis yang cukup mewarnai diskusi publik. ${ }^{8}$ Bahwa populisme ini dapat membahayakan demokrasi karena memiliki potensi untuk melahirkan otoritanianisme, ${ }^{9}$ dan memaksa presiden Jokowi untuk menggunakan pendekatan tidak liberal dan demokratis dengan mengeluarkan perppu bagi kelompok Muslim yang dianggap militan, konservatif, dan mengancam ideologi Pancasila. ${ }^{10}$ Situasi ini tentu saja adalah penanda bagi kemerosotan demokrasi dan pluralisme serta degradasi toleransi antar agama di Indonesia, yang tidak hanya menjadi tantangan bagi kelompok Muslim moderat dan pluralis saja, tetapi juga bagi kelompok liberal dan kiri yang cenderung absen dalam menantang arus politik tersebut. ${ }^{11}$

Fenomena di atas yang disebut juga sebagai "pembalikan konservatif" (conservative turn) ${ }^{12}$ dan "pembalikan otoritarian" (authoritarian turn), ${ }^{13}$ untuk menyebutnya secara simplistik, adalah simptom dari senjakala toleransi dan kerukunan umat beragama di Indonesia dengan segala dimensi dan lapisannya yang beragam.

04/19/world/asia/jakarta-election-ahok-anies-baswedan-indonesia.html;

The Guardian, https://www.theguardian.com/world/2017/feb/14/jakarta-governorelection-a-litmus-test-of-indonesian-islam; dan Council on Foreign Relations, https://www.cfr.org/interview/jakarta-election-signals-erosion-religious-tolerance.

8 Marcus Mietzner and Burhanuddin Muhtadi, "Explaining the 2016 Islamist Mobilisation in Indonesia: Religious Intolerance, Militant Groups and the Politics of Accommodation," Asian Studies Review, 42.3 (2018): 479-497.

9 Abubakar Eby Hara, "Populism in Indonesia and its Threats to Democracy." Third International Conference on Social and Political Sciences (ICSPS 2017), Atlantis Press, 2017.

10 Marcus Mietzner, "Fighting Illiberalism with Illiberalism: Islamist Populism and Democratic Deconsolidation in Indonesia," Pacific Affairs, 91.2 (2018): 261-282. Lihat juga Thomas P. Power, "Jokowi's Authoritarian Turn and Indonesia's Democratic Decline," Bulletin of Indonesian Economic Studies, 54.3 (2018): 307-338. Bandingkan dengan Vedi R. Hadiz, "Indonesia's Year of Democratic Setbacks: Towards a New Phase of Deepening Illiberalism?” Bulletin of Indonesian Economic Studies, 53.3 (2017): 261-278.

11 Vedi R. Hadiz, and Richard Robison, "Competing Populisms in Post-authoritarian Indonesia," International Political Science Review, 38.4 (2017): 488-502.

12 Muhammad Wildan, "Islamism and Democratization in the Post 411 and 212 Rallies of Indonesia," Thinking ASEAN. January, (2016). Bandingkan dengan Martin Van Bruinessen (ed.), Contemporary Developments in Indonesian Islam: Explaining the Conservative Turn, (Singapore: Institute of Southeast Asian Studies), 2013.

13 Thomas P. Power, "Jokowi's Authoritarian Turn and Indonesia's Democratic Decline," Bulletin of Indonesian Economic Studies, 54.3 (2018): 307-338. 
Berangkat dari sini, perlu kiranya melihat bagaimana toleransi dan kerukunan umat beragama dalam tingkat lokal dapat terwujud dan termanifestasikan dan sekaligus diangkat menjadi wacana publik untuk didiskusikan lebih jauh.

Kediri merupakan salah satu wilayah yang dikenal memiliki tingkat kerukunan agama tinggi. Baik di kota maupun di kabupaten, masyarakat Kediri menjunjung tinggi toleransi antar-agama. Ini misalnya dapat dilihat dari bagaimana pemerintah Kabupaten Kediri menggunakan city branding "Harmoni Kediri: The Service City" untuk menunjukkan karakteristik Kota Kediri yang aman, damai, dan penuh toleransi. ${ }^{14}$ Contoh lain yang lebih konkret juga bisa dilihat dari upaya masyarakat kelurahan Bangsal, Kecamatan Pesantren dan pemerintah Kediri dalam membangun dan menjaga toleransi dan kerukunan antar umat beragama dengan saling bekerjasama dan bergotong royong dalam segala hal, termasuk dalam bidang ekonomi, pendidikan, sosial dan budaya, serta keagamaan dan peribadatan. ${ }^{15}$ Di dusun Kalibago, pernikahan lintas agama bahkan sudah ada sejak tahun 1960an, dan menjadi tradisi yang berlangsung hingga saat ini. ${ }^{16}$ Selain itu, di Kota Kediri juga terdapat beberapa pusat keagamaan berbeda yang saling menghargai dan menghormati, seperti halnya beberapa pondok pesantren yang mewakili corak keberagamaan masyarakat Muslim, ada pula gereja, pura, wihara, dan klenteng yang menggambarkan keragaman agama di Kediri.

Upaya-upaya yang dilakukan ormas-ormas keagamaan di Kediri menunjukkan bahwa masyarakat beragama memiliki kesadaran tinggi untuk berbuat bagi kepentingan masyarakat dan kemaslahatan bersama. Hal itu merefleksikan panggilan agama yang menjadi sumber nilai perilaku dan aktivitas pemeluknya. Di sinilah letak kedewasaan beragama tersebut ditunjukkan.

\footnotetext{
14 Penjelasan lebih panjang terkait ini lihat: Irawan Hadi Wiranata dan Marzuki, "Kerukunan Antarumat Beragama Sebagai Dasar City Branding Harmoni Kediri The Service City," Jurnal Ilmiah Pendidikan Pancasila dan Kewarganegaraan, 3.1 (2019), 64-73.

15 Siti Makhmudah, "Upaya Masyarakat dalam Membina Kerukunan Antar Umat Beragama di Kelurahan Bangsal Kecamatan Pesantren Kota Kediri," El-Wasathiya: Jurnal Studi Agama, 4.2 (2016), 167-192.

16 Saiful Mujab, "Tinjauan Fenomenologi terhadap Pernikahan Lintas Iman di Dusun Kalibago Desa Kalipang Kecamatan Grogol Kabupaten Kediri,” Spiritualita, 2.1 (2018).
} 
Laporan setara Institute di tahun 2017 tentang daerah-daerah yang dinilai memiliki intoleransi tidak memasukkan kota Kediri ke dalam deretan 30 daerah yang terdata. ${ }^{17}$ Meskipun variabel intoleran yang diajukan Setara Institute lebih kepada peratuan-peraturan yang memiliki potensi konflik dan pernyataan kepala daerah atau elit politik daerah yang memilicu konflik, tetapi hal ini juga dapat menunjukkan tingkat keagamaan dan kerukunan di level masyarakat. Dalam konteks ini, menjadi menarik untuk melihat bagaimana kondisi kerukunan umat beragama di Kediri dapat berjalan, dimana peran dan pengaruh para pemimpin agama bekerja. Tokoh-tokoh agama jelas memiliki peran penting dalam menjaga kerukunan, baik di lingkungan internal agama maupun di ruang relasi lintas agama. Menghargai perbedaan dengan tidak menyebar ujaran-ujaran kebencian terhadap kelompok lain yang berbeda merupakan salah satu kunci upaya menjaga kerukunan tersebut.

Penelitian ini berupaya melihat bagaimana para tokoh agama di Kediri mampu menjaga kerukunan, bagaimana cara pandang mereka memahami perbedaan, dan bagaimana bangunan pemikiran mereka dalam menilai perbedaan agama. Penelitian ini juga mencoba menjawab bagaimana bangunan pemikiran tersebut tersusun dan terejawantah dalam terciptanya hubungan harmonis antar agama-agama di Kediri.

\section{Konstruksi Nilai Inklusif}

Nilai Inklusif hadir karena adanya sebuah perbedaan baik dalam hal fisik maupun kemampuan. Perbedaan tersebut dalam relasinya memunginkan suatu kondisi yang berpotensi menciptakan ketimpangan dan diskriminasi. Kondisi semacam ini ditemukan dalam teori pendidikan inklusif yang berangkat dari sebuah kondisi dimana terdapat anak didik yang kemampuannya beragam karena adanya keterbatasan fisik. Tujuan pendidikan inklusif adalah memberikan kesempatan seluas-luasnya kepada semua anak (termasuk anak berkebutuhan khusus) untuk mendapatkan pendidikan yang layak dan sesuai dengan kebutuhannya. ${ }^{18}$ Nilai inklusif yang lahir dalam persoalan agama akan beranjak menjadi

${ }^{17}$ Lihat lebih detail di http://setara-institute.org/indeks-kota-toleran-tahun-2017/

${ }^{18}$ Dadang Garnida, Pengantar Pendidikan Inklusif (Bandung: Refika Aditama, 2015), 43. 
teologi inklusif; yakni suatu pandangan keagamaan yang terbuka terhadap perbedaan yang ada. ${ }^{19}$

Alan Race membagi manusia dalam hubungannya dengan agama lain ke dalam tiga tipologi teologis: eksklusivisme, inklusivisme, dan pluralisme. Eksklusivisme bisa diartikan sebagai sikap yang menganggap agamanya sebagai satu-satunya agama yang benar dan agama lain sebagai jalan kesesatan. Sementara inklusivisme adalah suatu pandangan yang menganggap bahwa agama lain mengandung elemen kebenaran, tapi kebenaran dalam agamanya (sendiri) masih superior. Sedangkan pluralisme merupakan sebuah pandangan bahwa tidak ada agama yang superior, semua agama dianggap sebagai jalan yang absah menuju keselamatan. ${ }^{20}$

Masyarakat yang memiliki kesadaran inklusif akan lebih mudah mewujudkan upaya dialog antar-iman karena mereka meyakini bahwa orang yang menganut agama berbeda dengan diri kita juga berhak mendapatkan jalan keselamatannya sendiri, meskipun keselamatan yang sepenuhnya hanya dapat diperoleh melalui agama yang dianutnya. Hal ini berkebalikan dengan masyarakat eksklusif, yang memiliki pandangan bahwa agama lain harus mengikuti agamanya dan menolak upaya untuk melakukan dialog keagamaan secara terbuka. ${ }^{21}$

Seseorang atau sekelompok masyarakat yang memiliki pandangan inklusif dibentuk oleh beberapa faktor dan kondisi. Pertama, lingkungan sosial yang memungkinkan seseorang berpikir terbuka terhadap perbedaan. Kedua, masyarakat yang inklusif dibentuk dari kondisi historis, yakni sejarah panjang perjalanan masyarakat tersebut. Ketiga, masyarakat yang inklusif lahir karena kemampuan mereka dalam

\footnotetext{
${ }^{19}$ Konsep teologi inklusif dalam diskursus akademik lahir dari tradisi Kristianitas dalam konsep "Kristen Anonim" (Anonymous Christian) yang dipopulerkan oleh teolog Karl Rahner. Lihat dalam karyanya: "Anonymous Christians." Theological Investigations 6 (1969): 390-398. Dalam perkembangannya, ada dua tipe teologi inklusif yang lahir dari tradisi yang sama; yakni inklusivisme tradisional dan progresif. Rahner masuk pada kategori pertama, sedangkan yang kedua disematkan pada Paul Tillich. Lihat David Pitman, Twentieth Century Christian Responses to Religious Pluralism: Difference is Everything (London: Routledge, 2016), 93-123.

${ }^{20}$ Mun'im Sirry, "Mempertanyakan Eksklusivisme-Inklusivisme-Pluralisme dalam

Beragama," Geotimes.go.id. (diakses pada 11 November 2018).

${ }^{21}$ Fauzan Saleh, Existentialismus: Mengenali Keberadaan Tuban, Memaknai Pluralisme Agama, (Yogyakarta: Nadi Pustaka, 2015), 265.
} 
menerima perbedaan sebagai sebuah keniscayaan. Hal ini teruji berdasarkan pengalaman-pengalaman dalam kehidupan.

Peter L. Berger menyebutkan bahwa sebuah pelembagaan merupakan derivasi dari berbagai peristiwa, yaitu tipifikasi, historisitas, dan pengendalian. Tipifikasi adalah suatu model tindakan yang dilakukan secara berulang oleh orang tertentu dengan tindakan tertentu pula. Adapun historisitas adalah sejarah tentang suatu peristiwa tertentu yang teruji dari sejak kelahirannya hingga saat ini. Sementara pengendalian merupakan suatu mekanisme yang dilahirkan dari sebuah kebiasaan dalam bentuk kontrol terhadap tipifikasi yang sedang dijalankan. Merujuk pada hal tersebut, nilai inklusif memiliki kesamaan dengan konstruksi sosial yang dikonsepsikan oleh Berger. ${ }^{22}$

Nilai inklusif yang telah melembaga pada suatu masyarakat memiliki implikasi tersendiri. Implikasi nilai inklusif yang terinternalisasi dalam diri masyarakat adalah lahirnya sikap yang dapat menghargai kehadiran orang lain dengan segala keunikan dan keberbedaannya. Perubahan dari pandangan inklusif ini disebut sebagai aktualisasi nilai. Kesatuan antara pengetahuan, keyakinan akan sebuah pandangan yang inklusif serta melahirkan sikap yang sama dengan pandangan tersebut inilah yang disebut sebagai pluralisme. ${ }^{23}$

\section{Metode Penelitian}

Penelitian ini merupakan penelitian kualitatif dengan pendekatan konstruktivisme. Penelitian berlensa konstruktivisme cenderung tergantung pada pandangan partisipan tentang situasi yang diteliti. Penelitian konstruktivisme pada umumnya tidak dimulai dengan

\footnotetext{
22 Peter L. Berger dan Thomas Luckmann, The Social Construction of Reality, terj. Hasan Basari (Jakarta: LP3ES), 72-75.

${ }^{23}$ Eksponen pertama konsep pluralisme adalah John Hick yang menganggap bahwa Kristianitas bukanlah jalan satu-satunya keselamatan, melainkan hanya satu di antara sekian banyak. Lihat dalam bukunya, God and the Universe of Faiths: Essays in the Philosophy of Religion (Oxford: Oneworld, 1994). Dalam studi lebih lanjut, David Pitman membagi paham pluralisme dalam tradisi Kristianitas menjadi empat model: klasik pertama pada Hans Kung; klasik ke dua pada Raimundo Panikkar; pluralisme teosentris pada John Hick; dan pluralisme antroposentris pada Wilfred Cantwell Smith. Lihat penjelasan lebih panjang dalam bukunya, Twentieth Century Christian Responses to Religious Pluralism: Difference is Everything (Routledge, 2016), 144-215.
} 
seperangkat teori, namun mengembangkan sebuah teori atau sebuah pola makna secara induktif selama proses berlangsung. ${ }^{24}$

Objek penelitian ini adalah konstruksi nilai inklusif tokoh-tokoh empat agama di Kota Kediri, yaitu Islam, Kristen-Katolik, Hindu, dan Konghucu. Berikut daftar nama dan jumlah informan penelitian ini:

\begin{tabular}{|c|c|c|c|}
\hline No & Nama / Inisial & Agama & Status \\
\hline 1 & Prayitno & Konghucu & Ketua Klenteng Kediri \\
\hline 2 & Ketut Sugiarta & Hindu & Tokoh Agama Hindu \\
\hline 3 & Gus Ab & Islam & $\begin{array}{c}\text { Ketua PC NU Kota } \\
\text { Kediri }\end{array}$ \\
\hline 4 & Timotius Kabul & Kristen & Pendeta \\
\hline
\end{tabular}

Penggalian data dan wawancara dilakukan selama 3 bulan sejak Agustus hingga November 2018. Di dalam mengumpulkan data, penulis menggunakan dua metode utama, yaitu metode observasi atau pengamatan dan metode wawancara secara mendalam. Metode pengamatan terlibat digunakan untuk mengamati gejala-gejala yang terkait dengan ruang dan waktu, pelaku, kegiatan, benda-benda atau alat, peristiwa, tujuan, perasaan. ${ }^{25}$ Metode ini penggunaannya dikaitkan dengan pemahaman mengenai berbagai gejala yang berada di sekitar kehidupan informan. Ada dua aspek secara garis besar yang diteliti yaitu fisik dan non fisik. Kegiatan fisik yang diamati seperti geografi, keadaan sarana ibadah, keadaan saran pendidikan, dan lain-lain.

Aspek sosial juga diteliti seperti hubungan antar individu, individu dengan keluarga, masyarakat dengan ritualnya yang berkaitan erat dengan pranata sosial yang ada di lokasi penelitian. Sementara penelitian non fisik dilihat dari aspek budaya juga diteliti, simbolisasi dari upacara-upacara, tindakan-tindakan dari pelaku budaya yang terkait dengan upacara keagamaan yang sudah mengakar.

\footnotetext{
${ }^{24}$ John W. Creswell, Research Design: Qualitative, Quantitative, and Mixed Methods Approaches (London: Sage Publications, 2014), 8.

${ }^{25}$ Parsudi Suparlan, "Kata Pengantar" dalam Clifford Geertz, Abangan, Santri Priyayi dalam Masyarakat Jawa, terj. Aswab Mahasin, (Jakarta: Pustaka Jaya, 1981), 43-45.
} 
Sedangkan metode wawancara mengenai pendapat-pendapat, pemikiran-pemikiran yang berkait dengan kegiatan yang dilakukan oleh para informan baik terkait dengan tanggung jawab, peran serta perilaku lain yang terkait dengan pandangan hidup, etos yang melandasi berbagai tindakannya.

\title{
Hasil Penelitian
}

Penelitian ini melihat bahwa masyarakat Kediri secara umum memiliki pandangan inklusif. Hal ini dibentuk oleh tiga faktor utama, yaitu lingkungan sosial, kondisi historis, dan pengalaman-pengalaman dalam kehidupan beragama mereka.

\section{Tradisi Sosial Masyarakat Kediri}

Sebuah nilai adalah apa yang menjadi pegangan kuat di masyarakat, dan oleh karena itu budaya menjadi hal yang tidak bisa diabaikan. Wujud kebudayaan menurut Koentjoroningrat terdiri dari tiga bentuk. Pertama, mewujud dalam ide-ide, gagasan, falsafah hidup, dan ideologi. Kedua, wujud kebudayaan termanifestasikan dalam perilaku, kebiasaan hidup, tata cara mencari nafkah, dan semua perilaku yang nampak. Sementara bentuk kebudayaan yang ketiga mewujud dalam benda-benda peninggalan yang dihasilkan oleh manusia, artefak, manuskrip, bangunan, infrastruktur, dan lain sebagainya. ${ }^{26}$

Dalam hal kebudayaan, masyarakat Kediri memiliki falsafah hidup yang disebut dengan guyub rukun. Ketut Sugiarta seorang tokoh agama Hindu menyebutkan,

\begin{abstract}
"Sekarang kita hidup di Kediri, Kediri itu bisa menjadi kota percontohan juga karena adanya guyub rukun antar umat beragama. Adanya silaturahmi umat beragama. Contoh di lingkungan rumah saya kondisi sosial antar umat beragama saling bahu membahu, seperti bangun mushola itu bukan umat Muslim saja yang ikut andil dalam pembangunan, melainkan warga yang beragama lain seperti saya agama Hindu juga membantu dalam pembangunan mushola."
\end{abstract}

${ }^{26}$ Koentjaraningrat, Sejarab Teori Antropologi (Jakarta: UI Press, 1990), 186-187. 
Apa yang disampaikan Bapak Ketut di atas paling tidak menunjukkan dua hal. Pertama, bahwa ikatan solidaritas yang dimiliki oleh warga Kediri telah tumbuh di tengah masyarakat. Hal ini menunjukkan bahwa kebudayaan memainkan peranan penting dalam menciptakan ikatan solidaritas antar sesama warga Kediri, meskipun terdiri dari berbagai macam latar belakang agama dan keyakinan. Kedua, wujud kebudayaan guyub rukun sudah menjadi sistem perilaku masyarakat yang dengannya, rasa persatuan, gotong royong, dan saling membantu, tidak membutuhkan kesamaan identitas dalam beragama. Bahkan ketika berbeda, persaudaraan itu terlihat nyata.

Kebudayaan yang termanifestasikan dalam perilaku dapat terlihat dari berbagai aktifitas masyarakatnya. Seperti yang digambarkan oleh Ketut di atas, orang yang beragama Hindu tidak segan membantu sesama saudaranya dalam membangun rumah ibadah agama lain. Hal ini menunjukkan bahwa apa yang dilakukan Ketut sebagai seorang tokoh agama, akan menjadi contoh bagi pemeluk agamanya dalam berperilaku dalam kehidupan sehari-hari.

Selain Ketut, perilaku tokoh agama dalam menjaga semangat nilai budaya guyub rukun juga dicontohkan oleh Abdullah Abu Bakar (Gus $\mathrm{Ab}$ ) yang mewakili tokoh agama Islam dan sekaligus sebagai Ketua Pengurus Cabang Nahdlatul Ulama (PCNU) Kota Kediri. Menurut Gus $\mathrm{Ab}$,

"Karakter budaya masyarakat Kediri sudah terbangun kuat untuk tidak mudah terpancing emosi, mereka begitu cuek dalam menyikapi isu-isu nasional yang marak akhir-akhir ini. Sikap cuek yang dimaksud di sini bukan berarti mereka acuh pada persoalan, tetapi mereka menganggap bahwa perebutan klaim kebenaran dari masing-masing pihak yang berbeda tidak akan menambah apa-apa kecuali konflik dan disharmoni antara sesama umat manusia."

Pernyataan Gus Ab di atas menunjukkan bahwa budaya masyarakat Kediri adalah guyub rukun, suatu istilah yang dekat dengan pengertian harmoni. Menurutnya, kondisi sosial budaya masyarakat yang demikianlah yang berkontribusi besar dalam mengkonstruk pendangan hidup para tokoh agama. 
Keberadaan budaya guyub rukun juga didukung oleh peran pemerintah dalam menjaga dan melestarikan tradisi di setiap momen kedaerahan. Tema "Harmoni Kediri" pada ulang tahun Kediri tahun 2017 hingga saat ini masih dipakai. Tema besar ini digali dari nilai-nilai budaya Kediri yang menjaga kebersamaan dalam perbedaan. Dalam puncak perayaan ulang tahun tersebut, tradisi larung sesaji menjadi sajian dalam perayaan.

Larung sesaji merupakan tradisi yang dipegang teguh oleh masyarakat Kediri karena memiliki banyak makna. Selain perayaannya diselenggarakan di sungai Brantas, yang merupakan sungai terbesar di Kediri, tradisi ini juga disaksikan oleh warga masyarakat dari berbagai kalangan. Berikut dipaparkan makna-makna di balik tradisi tersebut:

1. Arak-arakan hasil bumi

2. Kenduren, rebutan berkah

3. Pelepasan kepala sapi ke sungai

4. Pelepasan dua ekor merpati

Menurut Nur Achyar, selaku kepala dinas Budaya dan Pariwisata Kota Kediri, tradisi larung sesaji merupakan bentuk rasa syukur masyarakat Kediri atas limpahan karunia berupa kesuburan tanah yang dapat menghasilkan berbagai macam hasil bumi yang dapat dinikmati oleh masyarakat. Selain tujuan budaya, menurut Asisten Daerah 1 Kota Kediri, Gendong, tradisi larung sesaji juga sebagai upaya pemerintah mensosialisasikan kepada masyarakat yang menyaksikan aktivitas ekonomi warga di sekitar sungai Brantas, agar dapat meningkatkan perekonomian mereka.

Hubungan harmonis antara tokoh agama dan pejabat pemerintah juga terjalin cukup kuat. Hal ini sebagaimana disampaikan oleh Gus Ab,

"Pemerintah cukup pro-aktif dalam menyikapi isu-isu nasional yang berpotensi memecah belah kerukunan antar anak bangsa. Beberapa hari yang lalu kami diundang oleh Kepolisian Resort Kota Kediri untuk menyampaikan pandangan kami terkait beberapa isu yang berkembang di Indonesia dan mendapat banyak perhatian masyarakat... Beberapa tokoh Muslim (para Kiai) meskipun dengan tegas mempertahankan ketidaksetujuannya pada beberapa kelompok agama yang dianggap melakukan 'makar' secara ideologi, namun tetap dewasa dalam menyikapi hal tersebut. 
Yakni dengan menyerahkan sepenuhnya kasus tersebut pada ranah hukum oleh pihak yang berwenang."

Apa yang disampaikan Gus Ab di atas menunjukkan bahwa tokoh-tokoh agama (terutama Islam) memegang peranan penting dalam menjaga kerukunan antar umat beragama. Ketidaksetujuan yang dimiliki oleh para tokoh agama di atas, tidak lantas diselesaikan dengan cara-cara yang tidak sesuai dengan norma dan adat kebiasaan masyarakat.

Pada kesempatan yang lain, Prayitno, seorang tokoh agama Konghucu yang juga menjadi ketua di Klenteng Kediri menuturkan bahwa kondisi lingkungan Kediri masih aman. Hubungan antar agama, baik tokoh masyarakat dan para pemimpin daerah melalui Forum Pimpinan Daerah (Forpimda) kota Kediri juga masih menjaga kebersamaan.

Selain menjadi ketua Klenteng di Kediri, Prayitno juga aktif terlibat dalam forum-forum kerukunan umat beragama yang diselenggarakan oleh berbagai macam organisasi baik di dalam Kediri maupun di luar Kediri. Pada 2017 ia pernah menghadiri undangan Setara Institute dalam rangka mewujudkan kota/kabupaten yang toleran sebagai percontohan kota-kota lain dalam menjaga kerukunan umat beragama. Kediri menjadi salah satu partisipan dalam acara sharing tentang pengelolaan kerukunan umat beragama tersebut.

Hal senada juga disampaikan pendeta Timotius Kabul (pendeta Kabul) yang peneliti wawancarai di kediamannya. Menurut Pendeta Kabul,

\footnotetext{
"Kerukunan masyarakat di Kediri dipengaruhi oleh kerukunan yang sudah dibangun oleh para tokoh agamanya. Jauh sebelum forum kerukunan yang dibuat oleh pemerintah (FKUB) tahun 2004, para tokoh agama sudah berinisiatif membangun komunikasi melalui pembentukan sebuah wadah Paguyuban Antar Umat Beragama dan Penghayat Kepercayaan (PAUB-PK). Hal ini terjadi karena para tokoh agama memiliki pandangan yang sama dalam membangun kerukunan, yakni yang sama tidak usab dibedabedakan, dan yang sudah beda jangan disama-samakan.
} 
Hubungan tokoh agama juga dikuatkan dengan tradisi jum'at kliwonan. Yaitu acara silaturahim antar tokoh dan umat beragama yang kegiatannya digilir di masing-masing agama. Meskipun namanya jumat kliwon, namun pada prakteknya bisa dilakukan di hari apapun."

Pendeta Kabul juga menyampaikan sesuatu yang terkait harmonisasi antar elemen masyarakat, yakni suatu sikap yang ditunjukkan oleh pemerintah dan tokoh agama, yakni ketika pemerintah harus memutuskan kebijakan-kebijakan tertentu yang terkait dengan masyarakat. Mereka selalu meminta pertimbangan para tokoh agama. Kata Pendeta Kabul,

\begin{abstract}
"Setiap kali pemerintah akan melakukan penggusuran terhadap pemukiman yang telah ditinggali oleh warga, kami selalu dimintai masukannya. Seperti penggusuran komplek prostitusi yang ada di Kediri, kami memberikan masukan dengan mendasarkan diri pada keyakinan agama kami.
\end{abstract}

Meskipun yang digusur tersebut merupakan kegiatan masyarakat yang dilarang dalam norma agama kami, namun bagaimanapun para pelakunya merupakan masyarakat kota Kediri yang herus diperhatikan secara sosial. pemerintah harus memberikan pembinaan kepada para warga yang lingkungan dan kegiatannya digusur tersebut.Inilah pelibatan kami yang dilakukan oleh pemerintah."

Apa yang disampaikan oleh pendeta Kabul di atas menunjukkan bahwa para tokoh agama juga sangat peduli dengan keberadaan masyarakat. Agama harus hadir dalam setiap kebijakan pemerintah yang berpotensi menciptakan disharmoni di dalam kehidupan masyarakat. Hal ini dapat menambah warna kerukunan di Kediri, karena dalam memberi pertimbangan, tokoh agama tidak melihat agama apa pada masyarakat yang dibela tersebut, tetapi lebih melihat sisi kemanusiaannya. Inilah hakikat kerukunan.

Kerukunan antar tokoh agama di Kediri diinisiasi salah satunya oleh Kiai Anwar Iskandar, Pendeta Kabul, dan beberapa tokoh agama lainnya. Kiai Anwar Iskandar beberapa kali disebutkan oleh pendeta 
Kabul sebagai orang yang pertama menginisiasi forum tersebut. Hal ini dalam pengamatan peneliti memiliki dampak yang besar bagi terwujudnya kegiatan kerukunan di Kediri, karena sosok Kiai Anwar merupakan seorang tokoh Agama Islam yang memiliki jumlah pemeluk terbesar di Indonesia termasuk Kediri, kehadirannya dan juga kontribusinya akan diikuti oleh masyarakat secara mayoritas yang diikuti oleh masyarakat lain yang non-muslim.

Selain mewawancarai para informan, peneliti juga mengamati kegiatan-kegiatan yang dilakukan para informan yang mendukung data tentang penelitian ini. Seperti yang tergambar dalam kegiatan yang dilakukan oleh jemaat Gereja GBI Getsamani yang di bawah pembinaan pendeta Kabul. Berikut beberapa cuplikan fieldnote penulis:

Rumah pendeta berada di samping Gereja GBI Getsamani. Pada saat peneliti menuju kediaman Pendeta Kabul, suasana di gereja sedang mengadakan kegiatan ibadah rabu. Peneliti datang sekitar pukul 18.30 dan kegiatan sedang berlangsung. Oleh pejaga gereja yang kebetulan bertemu di depan gereja, dengan ramah sang penjaga menanyakan maksud kedatangan peneliti. Lalu peneliti dipersilahkan untuk ikut menyaksikan prosesi ibadah yang dilakukan jemaah gereja.

Peneliti mengamati rangkaian kegiatan ibadah umat kristiani yang diawali oleh penyampaian seorang ibu yang memandu kegiatan. Ia menceritakan berbagai pengalaman hidup yang dirasakan dengan kehadiran tuhan. Ia juga meminta ke beberapa jemaah untuk menyampaikan testimony tentang kekuasaan Tuhan bekerja. Nampak seorang ibu setengah baya menyampaikan testimoninya dengan mengucap syukur atas keberkahan hidup dan keluarganya.

Setelah itu dilanjutkan pembacaan doa oleh petugas yang lain. Dalam doa tersebut ditunjukkan untuk segala hal yang berkaitan dengan kondisi bangsa, presiden dan wakilnya, TNI, Polri, Pemerintah propinsi, kabupaten, pengelenggaraan pilpres yang adil dan damai, semuanya didoakan agar berjalan sesuai dengan amanah dan berjalan secara baik dalam keberkahan Tuhan. Selian itu tidak lupa pula doa bagi segenap komunitas denomisai GBI di Kediri, para pendeta, pengurus yayasan, para jemaah, orang-orang yang sakit, serta kegiatan-kegiatan gereja. Semuanya didoakan agar dilimpahkan keberkahan Tuhan. 
Praktek ibadah umat Kristiani di atas menunjukkan beberapa hal. Pertama, ibadah mereka dilakukan dengan penuh khidmat, setiap jemaah memilki kesempatan yang sama dalam menyampaikan mukjizat tuhan yang ia rasakan di depan jemaah yang lain. Kedua, untaian doa yang dipanjatkan dibacakan dengan penuh penghayatan. Doa menjadi ruang komunikasi yang begitu intens dengan sang Tuhan. Selian itu, doa juga ditunjukkan kepada semua elemen bangsa, hal ini menunjukkan tingkat kepedulian mereka terhadap kondisi bangsa dan negeranya. Ketiga, doa menjadi kekuatan penopang keimanan umat kristiani dalam menjalankan segala aktifitas kehidupan. Mereka merasa yakin bahwa doa yang disampaikan dengan penuh kekhusyuan akan dijawab oleh Tuhan. Keyakinan ini berimplikasi pada penghormatan kepada sesama manusia, dengan tidak membedakan status agamanya. Seperti yang ditunjukkan oleh jemaah dan para pendeta yang mewakili pendeta Kabul dalam paparan berikut,

"Setelah mengikuti serangkaian kegiatan ibadah, peneliti masih belum bisa bertemu pendeta Kabul, karena masih memimpin doa terakhir. Namun ada seorang ibu pemandu ibadah doa tadi dan dua pendeta lain yaitu pendeta Yosua dan pendeta Thomas yang menghampiri peneliti dan menanyakan langsung dengan ramah maksud tujuan peneliti.

Setelah dijelaskan oleh peneliti, pendeta Yosua dan pendeta Thomas, mengungkapkan merasa senang dengan kehadiran peneliti dan dengan sigap mengantar peneliti menghampiri pendeta Kabul yang telah menyelesaikan doanya."

Keramahan yang ditunjukkan oleh pemeluk Kristiani menunjukkan bahwa mereka menghargai siapapun tanpa membedabedakan status agama yang diyakini oleh masing-masing manusia. Dalam paparannya pendeta Kabul juga berusaha untuk berbuat baik kepada sesama manusia dengan tidak membedakan agamanya. Hal ini dengan sendirinya akan membentuk pola keberagamaan dan kehidupan umat. 


\title{
2. Sosio Historis Masyarakat Kediri
}

Faktor kedua yang tidak dapat dipisahkan dari konstruksi nilai tokoh agama Kediri adalah sejarah tentang masyarakat Kediri itu sendiri. Dalam sejarahnya, Kediri hampir tidak pernah memunculkan gejolak berlebih yang dapat merusak harmonisasi masyarakat, baik sejarah dalam narasinya yang klasik maupun kontemporer.

Sejarah klasik tentang Kediri diungkapkan oleh Ketut Sugiarta. Menurutnya,

\begin{abstract}
"Kediri itu, dianggap kota tua dan menjadi barometer dari sisi spiritual dan sangat dituakan. Pada saat Mataram mulai runtuh, Empu Sinduk nglerek ngetan (pergi ke timur). Sebelum itu sudah ada prasasti (untuk menghormati leluhur) di telatah etan yakni ada di Kediri dan Kanjuruhan Malang. Kata 'Kediri' itu aslinya kadiri bukan kediri, artinya kembali ke jati dirinya. Orang-orang bisa belajar tentang jati dirinya pribadi, diri yang paling dalam, putih dan suci. Kita belum mengetahui pusat kerajaan Kediri tapi kirakira di Tondowongso Desa Nggurah Kab. Kediri.
\end{abstract}

Tokoh sejarah pada masa kerajaan di Kediri banyak salah satunya adalah raja Airlangga yang peninggalannya menjadi inspirasi kebangsaan, yakni garuda muka. Selain itu juga ada Sri Aji Jayabaya. Kediri menjadi sesuatu yang istimewa. Yakni sastra yang pertama kali berada di Kediri.

Sebelum adanya Panjalu dan Jenggala nama kerajaannya adalah Kahuripan. Sastra jawa mulai berkembang itu dimulai dari Kediri sehingga bisa menyebar ke daerah bali. Bahasa bali yang halus pun sama dengan bahasa jawa alus."

Dari pemaparan Ketut di atas, menunjukkan bahwa sejarah masyarakat Kediri, masih dipahami sebagai sejarah tentang harmonisasi antara manusia dengan manusia dan juga manusia dengan alamnya. Dengan pandangan sejarah seperti tersebut di atas, masyarakat Kediri seolah sedang "dituntut untuk" melanjutkan nilai-nilai yang telah dijalankan oleh para leluhur.

Sejarah Kediri adalah sejarah yang besar. Karena kebesaran sikap dan perjuangan para raja dan para leluhurnya. Seperti yang disampaikan 
oleh Ketut di atas, bahwa nama-nama leluhur Kediri telah mewariskan nilai-nilai besar yang bermanfaat dalam menjaga harmonisasi pada masyarakat Kediri. Kebesaran sejarah Kediri ditunjukkan dengan lahirnya sebuah lambang Garuda pertama kali yang ditemukan oleh raja Airlangga. Lambang ini seperti telah kita ketahui dijadikan sebagai lambang Negara Kesatuan Republik Indonesia (NKRI), sebagai simbol dalam menyatukan seluruh wilayah yang ada di tanah air.

Lambang burung Garuda, masih dapat kita saksikan di sekitar komplek pemakaman Syekh Ali Syamsuddin Al-Washil, yang merupakan seorang penyebar agama Islam dari Timur Tengah. ${ }^{27}$ Beberapa relief gambar burung Garuda dengan berbagai bentuknya yang terdapat di sekitar pemakaman Syekh Washil merupakan inspirasi lahirnya lambang negara. Selain itu, kehadiran Syekh Washil di tanah Kediri menunjukkan corak kebersatuan antara agama Hindu-Jawa dengan Islam. Syekh Washil dianggap sebagai orang yang mengajarkan ilmu ramalan kepada Sri Aji Joyoboyo. Masyarakat mengenal Sri Aji Joyoboyo ini selain sebagai seorang raja Kediri, juga sebagai orang yang mampu melahirkan ramalanramalan yang kelak di kemudian hari ramalan-ramalan tersebut terbukti. ${ }^{28}$

Selain sebagai sebuah warisan untuk dikenang dan dibanggakan, sejarah juga memiliki nilai mitologis. Nilai ini mengilhami para pemeluknya untuk tetap menjaga serta menjadikan nilai tersebut sebagai pegangan hidup dalam berperilaku. Sebagian masyarakat Kediri mengilhami tentang cerita raja-raja Kediri yang mampu menjaga hubungan dengan alam fisik dan alam metafisik. mangkatnya Sri Aji Joyoboyo ke surga nirwana dalam moksa-nya diyakini oleh masyarakat Kediri sebagai kesatuan antara manusia dengan realitas metafisik yang sesungguhnya. Mitos ini menjadi sebuah panduan hidup sebagian besar

\footnotetext{
27 Setidaknya ada dua versi terkait dengan asal-usul dari Syekh Ali Syamsuddin AlWashil. Ada yang menyebut dari negeri Rum/Persia. Lihat Agus Sunyoto, Atlas Walisongo (Tangerang: Pustaka Ilman, 2017), 64. Ada juga yang menyebut dari Mekah. Lihat Claude Guillot, Ludvik Kalus, dan Willem Molen, Inskeripsi Islam Tertua di Indonesia (Jakarta: Kepustakaan Populer Gramedia, 2008), 112.

${ }^{28}$ Kharisma Alfi Yunita, Study Kepercayaan Masyarakat Terbadap Kekeramatan Makam Syekh Al Wasil Syamsuddin di Setono Gedong Kota Kediri Tabun 1995-2008 (Surabaya: DisertasiUIN Sunan Ampel Surabaya, 2019), 43.
} 
masyarakat Kediri dalam meyakini keberadaan ralitas metafisik yang perlu diyakini keberadaannya.

Selain mitos tentang raja-raja, Kediri juga memiliki mitos yang dirawat dalam sejarah pengetahuan masyarakatnya. Sejarah tersebut adalah cerita tentang lembu suro, seorang bangsawan kerajaan Majapahit yang ingin mempersunting seorang putri cantik dari kerajaan Kediri, Dewi Kilisuci. Namun upaya Lembu Suro tersebut tidak mendapatkan hasil, karena Dewi Kiliisuci menolaknya, Lembu Suropun marah. Dalam kemarahannya, Lembu Suro yang memiliki kesaktian yang tinggi berjanji akan mengirimkan bencana kepada masyarakat Kediri berupa letusan Gunung Kelud. Hingga saat ini, mitor meletusnya Gunung Kelud masih dianggap sebagai kemurkaan Lembu Suro terhadap Dewi Kilisuci. ${ }^{29}$

Dalam kajian mitologi, sebuah cerita atau mitos memiliki makna yang mampu diinternalisasi oleh orang meyakininya. Mitos tersebut menjadi sistem nilai yang dengannya orang akan tunduk dan patuh. Masyarakat Kediri sendiri memiliki banyak mitos dalam kehidupannya. Selain tentang mitos lembu suro di atas, saat ini masyarakat Kediri juga meyakini tentang kekuatan sungai Brantas. Sungai yang dengannya ketika orang-orang yang memiliki jabatan tinggi di tingkat nasional melewati sungai tersebut, maka jabatan tersebut akan segera hilang atau dilengserkan.

Selain mitos soal lengsernya jabatan para tokoh nasional ketika melewati jembatan kali Brantas di atas. Sungai Brantas juga diyakini masih memiliki kekuatan untuk mencari korban "tumbal" jika dilakukan pembangunan jembatan yang menghubungkan wilayah timurnya sungai atau yang biasa dikenal dengan istilah etan kali dengan wilayah sebelah baratnya sungai kulon kali. Seperti penuturan Syamsul ketika peneliti bertanya kepadanya tentang kejadian kecelakaan yang menimpa seorang mahasiswa dan kecelakaan-kecelakaan lain yang hampir setiap hari terjadi di Kediri dan memakan korban jiwa. Menurut Syamsul, kejadian

29 Ita Kurnia, "Mengungkap Nilai-Nilai Kearifan Lokal Kediri Sebagai Upaya Pelestarian Budaya Bangsa Indonesia," Jurnal PGSD: Jurnal Ilmiah Pendidikan Guru Sekolah Dasar, 11.1 (2018): 56-57. 
kecelakaan itu merupakan bentuk "kemarahan" sungai Brantas akibat pembangunan jembatan baru. ${ }^{30}$

Terlepas dari berbagai keyakinan masyarakat terhadap mitosmitos tersebut di atas, serta pembenaran tentang mitos tersebut, peneliti melihat ada suatu fenomena menarik dari apa yang dipegang dan tertanam kuat dalam diri masayarakat Kediri. Mereka hampir pasti mengakui keberadaan mitos-mitos tersebut sebagai sebuah cerita yang tidak hanya menjadi simbol biasa, akan tetapi memiliki makna tertentu. Makna-makna yang bisa ditemukan dalam konteks ini antara lain adalah: (1) masyarakat masih meyakini keberadaan realitas metafisik atau gaib dalam kehidupan mereka. Realitas tersebut dianggap eksis dengan berbagai macam struktur dan sistemnya; (2) keberadaan makhluk gaib dan juga para leluhur masyarakat yang telah meninggal masih dipercaya dapat mengintervensi kehidupan manusia yang masih hidup. Oleh karena itu, perayaan dan tradisi yang disimbolkan untuk menghormati keberadaannya masih mudah dijumpai di kota Kediri. Inilah alasan mengapa masyarakat Kediri dikenal masih menjaga hubungan dengan realitas alam gaib.

Dari cara hidup seperti inilah masyarakat Kediri mengembangkan perilakunya dalam bermasyarakat. Mereka begitu menghargai manusia yang masih hidup, sebagaimana mereka menghargai dan meyakini keberadaan para leluhur mereka yang telah meninggal. Sehingga tidak sulit kita menemukan makam-makam dan petilasan para leluhur yang masih dikeramatkan oleh masyarakat Kediri.

Eksistensi tempat-tempat keramat tersebut, selain menjadi simbol sebagai pusat kesatuan antar warga sasat momen-momen sakral, juga memiliki dampak ekonomi yang penting bagi warga masyarakat di Kediri dari sejak zaman dahulu hingga era kontemporer seperti sekarang ini.

Fenomena kontemporer yang juga dapat diamati dalam perjalanan masyarakat Kediri digambarkan oleh Gus Ab sebagai berikut:

"Saya melihat dari dulu, kota Kediri itu aman, hampir tidak ada huru hara yang berarti di Kediri. Hal ini didukung oleh tingkat kenyamanan masyarakat Kediri dalam bidang ekonomi. Salah satu

${ }^{30}$ Wawancara dengan Syamsul, pada tanggal 15 November 2018 di Ngronggo Kediri. 
perusahaan besar yang menopang ekonomi masyarakat Kediri adalah PT. Gudang Garam.

Gudang Garam, dengan puluhan ribu karyawan, sejauh yang saya amati tidak pernah ada gejolak kasus yang besar. Hanya ada yang kecil-kecil, yang dilakukan oleh serikat buruh. Saya sempat diajak untuk melakukan aksi namun menolak. Pada akhirnya demo tersebut hanya dilakukan dengan doa bersama.

Fenomena ini menurut saya menunjukkan bahwa perusahaan (Gudang Garam) betul-betul menghormati hak-hak karyawan. Kalaupun terjadi pengurangan jumlah karyawan (PHK), uang pesangon yang diberikannya cukup besar dan sepadan.

Apa yang disampaikan Gus Ab di atas menunjukkan bahwa perjalanan sejarah Kediri, baik dari sisi sosial maupaun agamanya merupakan daerah yang minim mengalami pergolakan sosial yang signifikan di level masyarakat bawah. Hal tersebut dapat diatasi dengan sendirinya melalui sistem sosial dan sistem ekonomi masyarakatnya. Pemerintah dengan tokoh agama, juga tokoh agama dengan para pengusaha yang ada di Kediri, berusaha saling menjaga kepercayaan masing-masing.

\section{Pengalaman Keagamaan (Religious Experiences)}

Selain sosial budaya masyarakat, kontruksi nilai inklusif dalam beragama para tokoh agama juga dibentuk oleh seperangkat pemahaman dan pengalaman keagamaan mereka. Pemahaman dan pengalaman keeagamaan merupakan kejadian sehari-hari berupa keyakinan, perilaku serta pemaknaan yang terus menerus dari ajaran-ajaran agama yang dipraktekkan. Menurut Gus Ab,

"Pandangan tentang hidup, hakikat kebahagiaan tidak terlepas dari pemahaman terhadap ajaran Alquran. Dalam hal beragama, saya memegang prinsip ayat lakum dinukum wa liya din (untukmu agamamu dan untukku agamaku).” 
Senada dengan apa yang disampaikan Gus Ab di atas, Pendeta Kabul juga mengungkapkan hal berikut,

“.... saya suka dengan pendapat Rasul (Muhammad) yang menyebutkan kalimat lakum diinukum wa liya din. Dari kesukaan saya ini, saya dapat bergaul dengan para tokoh Muslim seperti Gus Solah (Pengasuh Pondok Pesantren Tebu Ireng Jombang), Pak Subakir (mantan Keu PCNU Kediri) dan pak Taufik (ketua Lembaga Seni Budaya Muslim PCNU Kediri).”

Pemaparan Gus Ab dan Pendeta Kabul di atas menunjukkan bahwa para tokoh agama memandang perbedaan agama di Kediri dengan selalu memegang prinsip terbuka, yakni menghargai keberadaan keyakinan masing-masing tanpa harus memaksakan keyakinan agama sendiri. Prinsip tersebut bersumber dari ajaran agama, seperti yang disebutkan oleh Gus Ab dan Pendeta Kabul, yakni ayat lakum dinukum wa liya din. ${ }^{31}$ Ayat tersebut berarti, "untuk kalian agama kalian, dan untukku agamaku."

\section{Pelembagaan Nilai Inklusif}

Konstruksi sosial menurut Berger merupakan gerak dialektis dari tiga momentum yang berupa internalisasi, objektivasi, dan eksternalisasi. Tokoh agama Kediri lahir dari lingkungan budaya yang terbuka dalam menerima setiap perbedaan keyakinan keagamaan, selama keyakinan tersebut tidak mengganggu stabilitas kehidupan masyarakat. Kenyataan ini diinternalisasi oleh para tokoh agama menjadi sistem nilai kehidupan.

Proses internalisasi dilakukan mula-mula dengan cara objektivasi budaya itu sendiri. Individu-individu secara independen mengamati keberadaan budaya inklusif sebagai sesuatu wujud. Pada momen ini subjektivitas memainkan peranan penting dalam mengamati sekaligus memahami budaya yang hadir di tengah-tengah mereka. Masyarakat dengan budayanya memberikan tindakan berpola (tipifikasi) yang dicerap secara langsung oleh individu. Proses pencerapan ini disebut dengan momen internalisasi.

31 Ahmed Ali, Al-Qur'an (New Jersey: Princeton University Press, 2001), 603. 
Wujud kebudayaan yang diamati merupakan tipifikasi yang telah melembaga seiring proses ekternalisasi yang dilakukan oleh individu. Hal tersebut lahir dari tindakan-tindakan individu yang berpola. Berger menyebutnya sebagai proses tipifikasi. Tipifikasi sendiri mengandaikan dua hal, pertama adalah tindakan yang berpola. Kedua adalah orang yang melakukan tindakan itu sendiri. Jadi, proses pencurahan kembali nilai yang diinternalisasi ke dalam dunia sosial dilakukan oleh individu tertentu dan melalui pola tertentu pula, serta melalui proses tertentu ia dilembagakan, momentum ini disebut sebagai proses eksternalisasi.

Dalam konteks konstruksi nilai inklusif tokoh agama di Kediri, proses objektivasi menjadi momentum pertama yang dilalui individu tokoh tersebut. Ia lahir dan mengamati budaya masyarakat Kediri yang telah memiliki kesadaran terbuka dalam merespon berbagai perbedaan pandangan. Budaya tersebut oleh individu (calon tokoh agama), diinternalisasi, yakni dicerap dalam diri individu sebagai sebuah nilai yang dengannya individu akan dibentuk.

Namun, apa yang diterima oleh individu dari hasil objektivasi tersebut tidak secara otomatis akan dicurahkan kembali secara persis ke dalam dunia sosial mereka. Menurut George Herbert Mead, individu akan melalui empat tahapan sebelum melakukan proses pencurahan nilai ke dalam sebuah tindakan, yaitu impuls, refleksi, manipulasi dan konsumsi. ${ }^{32}$ Proses refleksi dan manipulasi merupakan proses yang khas bagi manusia yang tidak dilakukan oleh makhluk lain seperti hewan, karena hal tersebut oleh manusia dilakukan dengan menggunakan rasionya.

Oleh karenanya, dalam momen eksternalisasi budaya terbuka dalam memandang perbedaan masyarakat Kediri yang telah dicerap oleh individu tidak akan selalu sama bentuknya dengan budaya yang pertama kali dicerap oleh individu. Kemampuan seseorang dalam merefleksikan dan memanipulasi sebuah impuls, akan selalu tidak sama. Di sinilah proses seleksi tindakan yang baru tersebut terjadi. Tipifikasi menjadi gambaran, tindakan mana yang akan disepakati secara sosial dan

32 George Ritzer and Jeffrey Stepnisky, Sociological Theory (London: Sage Publications, 2018), 424. 
kemudian dilembagakan oleh masyarakat sebagai objek dari proses eksternalisasi individu tersebut.

Dalam hal ini, budaya terbuka di dalam menerima perbedaan di masyarakat, bentuknya bisa sama namun memiliki kualitas yang beragam dari masing-masing individu tokoh agama di Kediri. Seperti yang dapat kita amati dari hasil wawancara dengan para tokoh agama, keragaman kualitas ini ditentukan pula oleh lingkungan terdekat dimana individu tinggal. Keluarga dan komunitas keagamaan sangat menentukan kualitas tersebut. Meskipun peneliti tekankan sekali lagi, bahwa secara garis besar para tokoh agama telah menginternalisasi budaya terbuka dalam beragama. Ini yang menjadi satu dari tujuh cultural universal yang digambarkan dalam konsepsinya Clyde Kluckhohn, yaitu sistem religi atau kepercayaan.

Menurut Clyde Kluckhohn dalam Soejono Soekanto menyebutkan bahwa unsur-unsur kebudayaan terdiri dari tujuh komponen yang disebutnya sebagai cultural universals, yaitu sistem religi/kepercayaan, peralatan dan perlengkapan hidup manusia, sistem kemasyarakatan, sistem pengetahuan, bahasa (lisan maupun tertulis), kesenian, dan sistem mata pencaharian hidup dan sistem-sistem ekonomi. ${ }^{33}$

Sistem keagamaan memungkinkan terjadinya interaksi seseorang dengan seseorang yang lain. Dalam sistem religi, interaksi tidak hanya menghadirkan simbol-simbol tanpa makna, lebih dari itu simbol yang dihadirkan adalah simbol yang memiliki makna karena lahir dari rahim agama yang mengajarkan tentang nilai-nilai keimanan.

Seorang individu yang dididik oleh orang tuanya dalam menjalankan ajaran agama akan menginternalisasi nilai-nilai ajaran tersebut. Intensitas interaksi dalam sistem religi ini memungkinkan seseorang memahami nilai-nilai ajaran agama yang akan menjadi pegangannya dalam menjalani kehidupan di dunia. Demikian juga dengan seorang tokoh agama. Umumnya para tokoh agama merupakan status warisan dari orang tua yang terlebih dahulu menjadi tokoh agama.

${ }^{33}$ Clyde Kluckhohn, dalam Soejono Soekanto, Sosiologi Suatu Pengantar (Jakarta: Rajawali Pers, 2013), 154. 
Seorang kiai dalam kebudayaan Jawa, hampir selalu merupakan anak keturunan dari seorang yang juga kiai. Sistem pendidikan yang diterapkan oleh orang tua akan mencerminkan sebutan atau status sosial yang sudah diberikan oleh masyarakat. Seorang kiai akan mengajarkan hal-hal yang fundamental terkait dengan ajaran agama kepada anaknya, menginjak dewasa sang anak akan dititipkan pada seorang kiai yang lain yang memiliki spesifikasi/kemampuan bidang agama tertentu. Begitupun seorang pendeta, romo, pendeta Hindu, dan biksu Buddha terlahir dari proses pendidikan nilai yang ditanamkan oleh orang tua, dan lingkungan masyarakatnya dalam menjalankan ritual agama. Inilah fase penanaman nilai seseorang melalui ajaran agama.

Pendidikan dalam kehidupan bermasyarakat terjadi pada setiap perilaku yang dihadirkan masyarakat. Seseorang akan menginternalisasi apa yang ia peroleh dari lingkungannya. Masyarakat Kediri yang lebih banyak menunjukkan proses interaksi secara intens, ditunjukkan dengan banyaknya kegiatan ritual seperti slametan, pernikahan, bahkan terjadi juga pada budaya cangkrukan, budaya nongkrong di warung kopi untuk sekedar bertemu dengan kawan dan melepas penat akibat aktifitas seharian. Budaya ngopi yang sudah mengakar di dalam masyarakat Kediri memiliki dampak positif dalam mengurangi prasangka-prasangka sosial terhadap satu golongan akibat perbedaan. Budaya cangkrukan menjadi simbol bagi kesatuan sosial masyarakat Kediri, yang di dalamnya secara tidak langsung mengajarkan kebersamaan dan kesalingtergantungan.

Selain itu terdapat pula majelis-mejelis pengajian yang diadakan oleh para pemimpin agama Islam bagi masyarakat Kediri yang tema kajiannya dapat diterima oleh semua kalangan, baik para pejabat hingga rakyat biasa. Seperti pengajian Gus Lik yang diselenggarakan setiap hari Selasa malam Rabu setelah Salat Isya. Masyarakat berduyun-duyun menghadiri pengajian tersebut hingga sebagian jalanan kota Kediri dipakai untuk tempat para hadirin yang ingin mendengarkan pengajian melalui pengeras suara.

Talcott Parson merumuskan konsepsi tentang struktur sebuah masyarakat dan menyatakan bahwa struktur sosial dapat bertahan dalam sebuah masyarakat ketika memenuhi empat unsur yang sering dikenal 
dengan istilah AGIL: adaptation, goal attainment, integration, dan latency pattern.

Adaptation atau adaptasi, merupakan suatu proses dimana suatu sistem harus mengatasi kebutuhan mendesak yang bersifat situasional eksternal. Sistem itu harus beradaptasi dengan lingkungannya dan mengadaptasikan lingkungan dengan kebutuhan-kebutuhannya. ${ }^{34}$ Perilaku keberagamaan yang terbuka dari para tokoh agama Kediri dalam konteks ini dipahami sebagai sistem tindakan yang berfungsi sebagai adaptasi atau penyesuaian diri terhadap sistem-sistem lain yang sudah berkembang di dalam masyarakat, seperti tradisi guyub rukun, dan toleransi. Perilaku ini juga sekaligus menunjukkan proses transformasi dunia eksternal para tokoh agama di Kediri.

Goal attainment atau pencapaian tujuan menjelaskan bahwa suatu sistem harus mendefinisikan dan mencapai tujuan utamanya. Perilaku keberagamaan yang inklusif telah mampu menguraikan tujuannya, yakni sebagai cara yang dianggap efektif dalam menciptakan hubungan sosial yang lebih harmonis di antara para pemeluk agama yang ada di Kediri. Selain itu, perilaku keberagamaan yang inklusif telah mampu memobilisasi sumber-sumber daya yang ada untuk mencapai tujuan tersebut, seperti penggunaan tafsir-tafsir keagamaan yang toleran, desain bangunan, serta mitos-mitos yang dibangun dalam rangka menjaga tujuan tersebut.

Integration bisa dijabarkan sebagai suatu sistem yang mengatur hubungan antar bagian-bagian dari komponennya. Ia juga harus mengelola hubungan di antara tiga imperatif fungsional lainnya (A, G, L). Pada bagian ini, perilaku keagamaan yang inklusif telah mampu menyatukan berbagai komponen di internal sistem itu sendiri seperti pola penyesuaian sistem dengan dan penguatan nilai-nilai, selaras dengan tujuan yang dibangun oleh sistem itu sendiri, yakni terciptanya hubungan sosial yang harmonis di antara para pemeluk agama di Kediri. Bagian ini juga difungsikan sebagai sistem yang mampu mengendalikan bagianbagian ketiga sistem yang lainnya.

34 Talcott Parson dalam George Ritzer, Sociological Theory, Terj. Saut Pasaribu, dkk, Teori Sosiologi dari Klasik Sampai Perkembangan Terakhir Postmodern, (Yogyakarta: Pustaka Pelajar, 2014), 408-411. 
Latency pattern (pemeliharaan pola) bermakna, suatu sistem harus menyediakan, memelihara, dan memperbarui baik motivasi para individu maupun pola-pola budaya yang menciptakan dan menopang motivasi itu. Perilaku keagamaan yang inklusif adalah wujud dari nilai inklusif itu sendiri. Nilai ini mampu dipelihara melalui pemeliharaan pola-pola tindakan yang mendukung langgengnya nilai ini diinternalisasi oleh para tokoh agama di Kediri. Pola-pola keagamaan menjadi salah satu yang dapat dilihat sebagai penjaga nilai-nilai inklusif pada masyarakat Kediri.

Dari konsepsi yang dirumuskan oleh Parson di atas menunjukkan bahwa perilaku keagamaan yang inklusif dari para tokoh agama di Kediri dalam memandang pluralitas agama, telah memenuhi syarat bagi penerimaan dan pelanggengan perilaku tersebut. Sistem tindakan, sistem kepribadian, sistem sosial dan sistem budaya dalam rumusan Parson di atas telah mengkonstruksi nilai dan perilaku beragama yang inklusif.

\section{Pencurahan Kembali Pandangan Inklusif dalam Keseharian}

Sistem keagamaan dan upacara keagamaan, menunjukkan watak harmonis dan kebersamaan. Setiap praktek peribadatan yang dilakukan oleh agama selalu mengedepankan aspek kebersamaan dan keteraturan. Salat, puasa dan haji dalam Islam; ibadat mingguan dan Perjamuan Kudus dalam Kristen; sembahyang dalam Hindu, Buddha dan Konghucu, menunjukkan watak kebersamaan karena dilakukan tidak oleh individu-individu dalam ruang-ruang privat (meski boleh dilakukan) namun dilakukan secara bersama-sama dalam satu momen dan tempat yang telah disediakan oleh masing-masing agama. Masjid, gereja, pura, wihara dan klenteng adalah tempat-tempat yang disucikan oleh pemeluk agama dan menjadi pusat ibadah yang dilakukan secara berjemaah (bersama sama dalam keteraturan). Ini juga yang ditunjukkan oleh masyarakat Kediri yang secara umum adalah masyarakat penganut agama-agama.

Ikatan kebersamaan yang dilakukan pada momen-momen ibadah (berjemaah) seringkali tidak menemukan bentuk (jemaah) yang sama dalam hal kehidupan sehari-hari yang menyangkut urusan dunia, seperti dalam kehidupan bermasyarakat, baik di kantor maupun di lingkungan tempat tinggal. Hal ini terjadi karena beberapa hal. Pertama, karena 
kesibukan masing-masing orang yang menuntut mereka untuk bekerja sendiri-sendiri seperti pada masyarakat di kota. Kedua, karena tidak kuatnya nilai budaya yang mengikat semua warga untuk menciptakan budaya kebersamaan, baik di kantor, sekolah, ruang publik, maupun di lingkungan sekitar rumah warga.

Maka untuk mewujudkan kebersamaan tersebut, selain harus mengaktualisasikan nilai kebersamaan yang diperoleh dari ritual beragama, juga harus ditopang atau diperkuat dengan keberadaan nilainilai budaya yang mengarah pada kebersamaan tersebut. Hal ini yang terasa nampak dalam kultur masyarakat Kediri. Selain para pemimpinnya menunjukkan sikap kebersamaan, mereka juga tidak berusaha membedabedakan keyakinan yang dipegang oleh masing-masing agama.

Melalui berbagai organisasi yang menaungi kerukunan agama seperti Forum Kerukunan Umat Beragama (FKUB), Paguyuban Antar Umat Beragama dan Penghayat Kepercayaan (PAUB-PK) serta forumforum lintas iman yang ada di kota Kediri, seperti Paguyuban Lintas Masyarakat (PaLM), para tokoh agama berusaha menjaga suasana kebesamaan dalam perbedaan tersebut. Forum-forum tersebut dianggap efektif dalam menjaga semangat kebersamaan dalam rangka menjaga kota Kediri lebih kondusif.

Dalam forum-forum tersebut, nilai-nilai inklusif (terbuka) dalam beragama hadir dan terinternalisasi dalam diri masing-masing tokoh agama yang tercermin dalam pengalaman-pengalaman hidup dan tersimpan dalam kesadaran mereka. Seperti ungkapan Peter L. Berger,

Pengalaman-pengalaman yang tersimpan terus itu lalu mengendap; artinya, menggumpal dalam ingatan sebagai entitas yang bisa dikenal dan diingat kembali. ... Pengendapan intersubjektif juga terjadi apabila beberapa individu mengalami suatu biografi bersama, di mana pengalaman-pengalamannya lalu menjadi bagian dari suatu cadangan pengetahuan bersama. ${ }^{35}$

Nilai inklusif menjadi satu pegangan para tokoh agama di Kediri karena intensitas pertemuan yang tinggi. Hampir sebulan sekali forum-

35 Peter L. Berger, dan Thomas Luckmann, The Social Construction of Reality, 92. 
forum kerukunan di atas melakukan kegiatan anjang sono atau silaturahim yang digilir di masing-masing agama sebagai tuan rumah.

Anjang sono forum kerukunan umat beragama ini menjadi sistem tanda yang memungkinkan terjaganya nilai-nilai inklusif oleh masingmasing tokoh agama di Kediri. Selain itu, silaturahmi antar tokoh agama ini menjadi simbol yang mampu diwariskan dari satu generasi ke generasi lainnya. Hal ini disebut oleh Berger sebagai kolektivitas yang terbentuk dari dari pengulangan-pengulangan objektifikasi pengalaman-pengalaman bersama. $^{36}$

\section{Penutup}

Perilaku keagamaan inklusif masyarakat Kediri ditopang kuat oleh keberadaan para tokoh agamanya yang mampu mencerap nilai-nilai harmoni yang mengakar di masyarakat. Hal tersebut terbentuk melalui proses yang disebut sebagai dialektika sosial, yakni gerak dialektis dari tiga momen: objektivasi, internalisasi dan eksternalisasi. Pada momen objektivasi, seorang tokoh agama merupakan individu yang mengamati masyarakat dan lingkungannya sebagai sebuah objek yang riil.

Sementara pada momen internalisasi, seorang tokoh agama mencerap nilai-nilai yang terdapat dalam masyarakat Kediri sebagai hasil objektivasinya. Nilai tersebut mewujud dalam tiga hal. Pertama, sosio kultur masayarakat Kediri yang menjadikan nilai harmoni sebagai landasan hidup masyarakat. Kedua, sosio-historis, yakni pewarisan sejarah masa lalu Kediri yang masih menjadi panduan secara berkesinambungan dari satu generasi ke generasi berikutnya. Ketiga, nilai yang mewujud dalam pengalaman-pengalaman keagamaan yang intens dan mendalam dalam menghayati dan melaksanakan ajaran-ajaran agamanya. Ketiga komponen inilah yang mengkonstruk nilai inklusif tokoh masyarakat Kediri yang dengannya menjadi panduan perilaku para pemeluk agama (jemaah) yang lain.

${ }^{36}$ Ibid., 22. 


\section{Daftar Pustaka}

Afdillah, Muhammad. Dari Masjid ke Panggung Politik: Melacak. Akar-akar Kekerasan Agama antara Komunitas Sunni \& Syiah di Sampang, Jawa Timur. Yogyakarta: CRCS, 2016.

Ali, Ahmed. Al-Qur'an. New Jersey: Princeton University Press, 2001.

Bagir, Zainal Abidin, et al. Membatasi Tanpa Melanggar: Hak Kebebasan Beragama atau Berkeyakinan. Yogyakarta: CRCS, 2019.

Berger, Peter L, dan Luckmann, Thomas. The Social Construction of Reality (terj. Hasan Basari). Jakarta: LP3ES, 2012.

Burhani, Ahmad Najib. "Treating Minorities with Fatwas: A Study of the Ahmadiyya Community in Indonesia." Contemporary Islam, 8.3 (2014): 285-301.

Crouch, Melissa. "Ahmadiyah in Indonesia: A History of Religious Tolerance Under Threat?" Alternative Law Journal, 36.1 (2011): 5657.

Garnida, Dadang. Pengantar Pendidikan Inklusif. Bandung: Refika Aditama, 2015.

Geertz, Clifford. Abangan, Santri Priyayi dalam Masyarakat Jawa. Jakarta: Pustaka Jaya, 1981.

Guillot, Claude, Ludvik Kalus, dan Willem Molen. Inskripsi Islam Tertua di Indonesia. Jakarta: Kepustakaan Populer Gramedia, 2008.

Hadiz, Vedi R. "Indonesia's Year of Democratic Setbacks: Towards a New Phase of Deepening Illiberalism?." Bulletin of Indonesian Economic Studies, 53.3 (2017): 261-278.

Hadiz, Vedi R., and Richard Robison. "Competing Populisms in Postauthoritarian Indonesia." International Political Science Review, 38.4 (2017): 488-502.

Hara, Abubakar Eby. "Populism in Indonesia and its Threats to Democracy." Third International Conference on Social and Political Sciences (ICSPS 2017). Atlantis Press, 2017.

Hick, John. God and the Universe of Faiths: Essays in the Philosophy of Religion. Oneworld Oxford, 1994.

Hilmy, Masdar. "The Political Economy of Sunni-Shi'ah Conflict in Sampang Madura." Al-Jami'ab: Journal of Islamic Studies, 53.1 (2015): 27-51. 
John W. Creswell. Research Design: Qualitative, Quantitative, and Mixed Methods Approaches. Sage Publications, 2014.

Koentjaraningrat. Sejarah Teori Antropologi. Jakarta: UI Press, 1990.

Kurnia, Ita. "Mengungkap Nilai-Nilai Kearifan Lokal Kediri Sebagai Upaya Pelestarian Budaya Bangsa Indonesia." Jurnal PGSD: Jurnal Ilmiah Pendidikan Guru Sekolah Dasar, 11.1 (2018): 51-63.

Ma'arif, Samsul. Pasang Surut Rekognisi Agama Lelubur dalam Politik. Agama di Indonesia. Yogyakarta: CRCS, 2017).

Makhmudah, Siti. "Upaya Masyarakat dalam Membina Kerukunan Antar Umat Beragama di Kelurahan Bangsal Kecamatan Pesantren Kota Kediri." El-W asathiya: Jurnal Studi Agama, 4.2 (2016), 167-192.

Marshall, Paul. "The Ambiguities of Religious Freedom in Indonesia. The Review of Faith \& International Affairs, 16.1 (2018): 91.

Mietzner, Marcus, and Burhanuddin Muhtadi. "Explaining the 2016 Islamist Mobilisation in Indonesia: Religious Intolerance, Militant Groups and the Politics of Accommodation." Asian Studies Review, 42.3 (2018): 479-497.

Mietzner, Marcus. "Fighting Illiberalism with Illiberalism: Islamist Populism and Democratic Deconsolidation in Indonesia." Pacific Affairs, 91.2 (2018): 261-282.

Mudzakkir, Amin. "Minoritisasi Ahmadiyah di Indonesia." Masyarakat Indonesia, 37.2 (2011): 1-25.

Mujab, Saiful. "Tinjauan Fenomenologi terhadap Pernikahan Lintas Iman di Dusun Kalibago Desa Kalipang Kecamatan Grogol Kabupaten Kediri.” Spiritualita, 2.1 (2018).

Pitman, David. Twentieth Century Christian Responses to Religious Pluralism: Difference is Everything. Routledge, 2016.

Power, Thomas P. "Jokowi's Authoritarian Turn and Indonesia's Democratic Decline.” Bulletin of Indonesian Economic Studies, 54.3 (2018): 307-338.

Rahner, Karl. "Anonymous Christians.” Theological Investigations, 6 (1969): 390-398.

Ritzer, George and Jeffrey Stepnisky. Sociological Theory. Sage Publications, 2018. 
Ritzer, George. Teori Sosiologi dari Klasik Sampai Perkembangan Terakhir Postmodern. Yogyakarta: Pustaka Pelajar, 2014.

Saleh, Fauzan. Existentialismus: Mengenali Keberadaan Tuban, Memaknai Pluralisme Agama. Yogyakarta: Nadi Pustaka, 2015.

Soekanto, Soerdjono. Sosiologi Suatu Pengantar. Jakarta: Rajawali Pers, 2013.

Sunyoto, Agus. Atlas Walisongo. Tangerang: Pustaka Ilman, 2017.

Van Bruinessen, Martin, ed. Contemporary Developments in Indonesian Islam: Explaining the Conservative Turn. Institute of Southeast Asian Studies, 2013.

Wildan, Muhammad. "Islamism and Democratization in the Post 411 and 212 Rallies of Indonesia." Thinking ASEAN. January (2016).

Wiranata, Irawan Hadi, dan Marzuki. "Kerukunan Antarumat Beragama Sebagai Dasar City Branding Harmoni Kediri The Service City." Jurnal Ilmiah Pendidikan Pancasila dan Kewarganegaraan, 3.1 (2019), 64-73.

Yunita, Kharisma Alfi. Study Kepercayaan Masyarakat Terbadap Kekeramatan Makam Syekh Al Wasil Syamsuddin di Setono Gedong Kota Kediri Tahun 1995-2008. Diss. UIN Sunan Ampel Surabaya, 2019.

\section{Internet}

Abdillah, Masykuri. http://graduate.uinjkt.ac.id/index.php/akademik/2016-12-01-09-12-13/12-kolom-direktur/156-kerukunanumat-beragama-di-era-jokowi-jk. diunduh pada 28 September 2018

Albert, Eleanor dan Brooks, Karen B. "Jakarta Election Signals Erosion of Religious Tolerance." https://www.cfr.org/interview/jakartaelection-signals-erosion-religious-tolerance. (diakses pada 18 Desember 2019).

Cochrane, Joe. "Jakarta Governor Concedes Defeat in Religiously Tinged Election." https://www.nytimes.com/2017/04/19/world/asia/jakarta-election-ahok-anies-baswedan-indonesia.html. (diakses pada 18 Desember 2019).

Lamb, Kate. 'Jakarta Governor Election a 'Litmus Test' of Indonesian Islam." https://www.theguardian.com/world/2017/feb/14/jakarta- 
governor-election-a-litmus-test-of-indonesian-islam. (diakses pada 18 Desember 2019).

Setara Institute dan Unit Kerja Presiden-Pembinaan Ideologi Pancasila. "Ringkasan Eksekutif Indeks Kota Toleran (IKT) Tahun 2017." http://setara-Institute.org/indeks-kota-toleran-tahun-2017/. (diakses pada 15 Desember 2019).

Sirry, Mun'im. "Mempertanyakan Eksklusivisme-Inklusivisme-Pluralisme dalam Beragama." geotimes.go.id. (diakses pada 11 November 2018). 